\title{
Community structure of aquatic insects in the Esparza River, Costa Rica
}

\author{
Jonathan Herrera-Vásquez \\ Maestría en desarrollo sostenible, Universidad de Costa Rica, Sede de Occidente; jonnabio@gmail.com
}

\author{
Received 13-VI-2008. C Corrected 22-IX-2008. Accepted 23-X-2008.
}

\begin{abstract}
Community structure of aquatic insects in the Esparza River, Costa Rica. This study focused on the structure of the aquatic insect community in spatial and temporal scales in the Esparza River. The river was sampled for one full year throughout 2007. During the dry season low flow months, five sampling points were selected in two different habitats (currents and pools), with five replicates per sample site. During the wet season with peak rain, only the data in the "current habitat" were sampled at each site. Specimens present in the different substrates were collected and preserved in situ. A nested ANOVA was then applied to the data to determine richness and density as the response variables. The variations in temporal and spatial scales were analyzed using width, depth and discharge of the river, and then analyzed using a nested ANOVA. Only a correlation of 51\% similarity in richness was found, while in spatial scale, richness showed significant variation between sampling sites, but not between habitats. However, the temporal scale showed significant differences between habitats. Density showed differences between sites and habitats during the dry season in the spatial scale, while in the temporal scale significant variation was found between sampling sites. Width varied between habitats during the dry season, but not between sampling points. Depth showed differences between sampling sites and season. This work studies the importance of community structure of aquatic insects in rivers, and its relevance for the quality of water in rivers and streams. Rev. Biol. Trop. 57 (1-2): 133-139. Epub 2009 June 30.
\end{abstract}

Key words: Aquatic insects, community structure, water quality, Esparza River, Costa Rica.

Variation in ecosystems can occur both by the effect of human activities and naturally due to the environmental factors changing in temporal and spatial scales. Understanding the ecology of the aquatic insects in Costa Rican rivers is a major topic in applied research of water quality in order to better understand the changes caused by the various disturbing factors in rivers in reference to pristine uncontaminated environments.

Community structure of the aquatic organisms of rivers and streams is a highly useful tool in biological integrity analysis (DeShon 1995, Karr \& Chu 1999, Oberdoff et al. 2001) due to its specific and predictable responses to changes in landscape and physical-chemical factors, and is relatively easy to measure and interpret (Karr \& Chu 1999).
In Costa Rica, there is insufficient knowledge concerning insect community structures in rivers. Only a few studies on this topic have been done to answer the questions about distribution, abundance and richness of species in the rivers. The resulting data found confusing relationships between variables, complicating the data analysis and pattern inference (Abel 1989, Rosemberg \& Resh 1993, Stein et al. 2007).

This study was carried out in the Esparza River located on the central Pacific slope near the town of Esparza (24 000 inhabitants). It has a longitude of $10 \mathrm{~km}$ from its source in the slopes of the hills in the southeast zone of the central district and flows into the Barranca River about five kilometers before the Pacific Ocean. According to the life zone system 
(Holdridge 1967) the river is located in the tropical humid forest (bh-T). The study zone is a second order river with a slow drainage system and a smooth pendent. The intent of this research is to analyze the variability of the aquatic insect community in the Esparza River on a spatial and temporal scale.

\section{MATERIALS AND METHODS}

Aquatic insects present in sand, gravel, small rocks, fallen leaves, sticks and organic matter were collected throughout 2007 in the Esparza River. During the driest, low flow months five sections were selected each $100 \mathrm{~m}$ long, separated by $500 \mathrm{~m}$ between each section. Each section for sampling was labeled from A to E, starting up-stream (Fig. 1). Inside of every section five current points and five pools were chosen, and five replicates in every point were taken (Moya \& Oberdorff 2006). During the wet season with peak rain, only the current points at every station were sampled, using a total of 75 replicates for the study.

The samples were obtained disturbing the substrate by hand and collecting the specimens using a strainer of $0.02 \mathrm{~m}^{2}$ with a mesh of

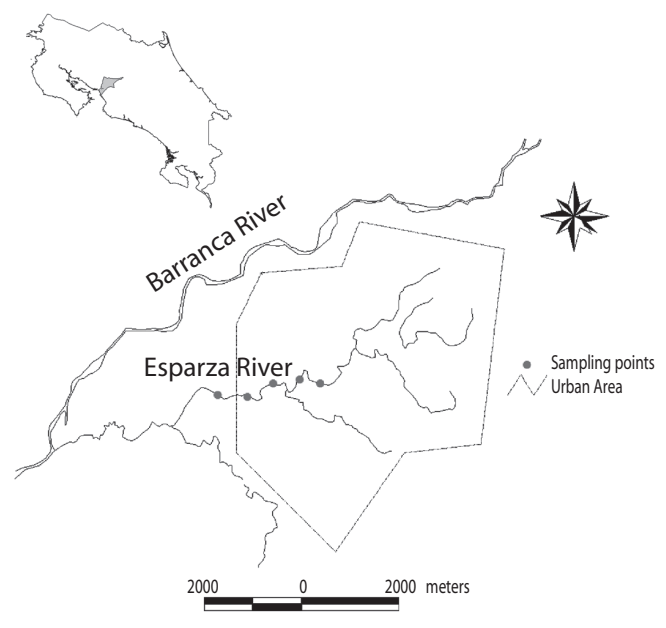

Fig. 1. Sampling points in the Barranca River Basin and study zone, Esparza River, Costa Rica. The populated area was estimated based upon topographic maps and approximate information.
$450 \mu \mathrm{m}$ (Springer \& Maue 2006). Then the specimens were sorted in vials and preserved in $80 \%$ ethanol for further identification in the laboratory to the genus level (Roldán 1996). The sampling scheme included two nested spatial scales: habitat (pools/current) and sampling station (nested within habitat). The temporal dimension includes the season (wet/dry) with the station nested in.

In each replicate the maximum depth, width, temperature, season and discharge of the river were recorded during the sampling period according to the methods suggested by the Environmental Protection Agency of the United States of America (USEPA 1997).

To analyze variation in discharge, a t-student test was applied looking for differences between pool/current during the dry season, and between seasons, applied to currents only. To determine the differences between width and depth in the non-biological variables, a nested ANOVA was applied searching for significant changes within and between pool/current sampling sites during the dry season.

Every sample was described ecologically in terms of density (total individuals per sample) and richness (number of taxa per sample) (Krebs 1999, Boyero \& Bailey 2001). To determine the variation at the community level, a nested ANOVA (Bailey 1992) was applied detecting the change in spatial scale (site nested in habitat) and temporal scale (site nested in season), using richness and density as the response variables. The coefficient of correlation was then calculated between richness and density, with the sample point considered as the error term in the analysis. Finally, species accumulation curves were drawn for both seasons taking into account all the information from all sites.

\section{RESULTS}

A total of 1837 individual insects were collected belonging to 20 families and 26 genera (Table 1). The average water temperature in the entire sampling period was $23.4{ }^{\circ} \mathrm{C}$ (Min=22, Max=25, $\mathrm{n}=26)$. The discharge did 
TABLE 1

Taxa found at the Esparza River in samples of leaf litter in currents and pools during 2007

\begin{tabular}{|c|c|c|}
\hline Genus & Current & Pool \\
\hline Ambrysus & $\mathrm{X}$ & \\
\hline Argia & $\mathrm{X}$ & $\mathrm{X}$ \\
\hline Belostoma & & $\mathrm{X}$ \\
\hline Caenis & $\mathrm{X}$ & $\mathrm{X}$ \\
\hline Camelobaetidius & $\mathrm{X}$ & $\mathrm{X}$ \\
\hline Cercobrachys & & $\mathrm{X}$ \\
\hline Chelifera & $\mathrm{X}$ & \\
\hline Chimarra & $\mathrm{X}$ & $\mathrm{X}$ \\
\hline Chironominae & & $\mathrm{X}$ \\
\hline Corydalus & $\mathrm{X}$ & $\mathrm{X}$ \\
\hline Farrodes & $\mathrm{X}$ & $\mathrm{X}$ \\
\hline Hetaerina & $X$ & $\mathrm{X}$ \\
\hline Heteragrion & $\mathrm{X}$ & $\mathrm{X}$ \\
\hline Leptohyphes & $\mathrm{X}$ & $\mathrm{X}$ \\
\hline Leptonema & $\mathrm{X}$ & \\
\hline Limnocoris & $\mathrm{X}$ & $\mathrm{X}$ \\
\hline Macrothemis & $\mathrm{X}$ & $\mathrm{X}$ \\
\hline Microvelia & & $\mathrm{X}$ \\
\hline Odontomyia & & $\mathrm{X}$ \\
\hline Pelonomus & $\mathrm{X}$ & $\mathrm{X}$ \\
\hline Phyllogomphoides & $\mathrm{X}$ & $\mathrm{X}$ \\
\hline Progomphus & $\mathrm{X}$ & $\mathrm{X}$ \\
\hline Rhagovelia & $\mathrm{X}$ & \\
\hline Simulium & $\mathrm{X}$ & \\
\hline Smicridea & $\mathrm{X}$ & \\
\hline Thraulodes & $\mathrm{X}$ & $\mathrm{X}$ \\
\hline
\end{tabular}

not show significant difference between pools $\left(X=0.244 \mathrm{~m}^{3} / \mathrm{s}\right)$ and currents $\left(X=0.332 \mathrm{~m}^{3} / \mathrm{s}\right)$ $(\mathrm{t}=1.654, \mathrm{p}=0.132, \mathrm{n}=25)$. However, the comparison between dry and rainy season measured in currents did show significant difference $(\mathrm{t}=4.476, \mathrm{p}<0.01, \mathrm{~N}=25)$. During the dry season, the variation in the river width was mainly among habitat conditions, and no differences between sampling sites were found. The river depth between seasons was significantly higher in pools $(X=30.06 \mathrm{~cm})$ than in currents $(X=$ $21.73 \mathrm{~cm}$ ), and also between sites nested to season (Table 2).

In both seasons and habitat conditions, the accumulation curves showed that after the fifth sample it is still possible to find new taxa. The samples obtained in the currents during the dry season showed the best tendency to stabilize the curve (Fig. 2). Eleven genera were present only in one habitat type (pool or current) giving a similarity of $57.7 \%$. The most common and abundant genera found in all samples and all periods (more than 150 specimens per taxa) were Farrodes sp., Chimarra sp., Leptohyphes $s p$ and Argia sp.. The least number of individuals (three specimens) was registered in the fifth replicate at site $\mathrm{A}$ in the current during the dry period, and the most (125 specimens) in the second replicate of site $B$ in the current during the dry period.

The nested ANOVA showed that richness during the dry season experiment had

TABLE 2

Results of the nested ANOVA for the abiotic variables river width and maximum depth among pools $(X=30.06 \mathrm{~cm})$ and currents $(X=21.73 \mathrm{~cm})$ during the dry season. $N=50 . M S=$ Mean squares, $d f=$ degrees of freedom,

$$
F=F-\text { test value, } p=\text { Probability }
$$

\begin{tabular}{lcccc}
\multicolumn{1}{c}{ Source } & df & MS & F & P \\
Width & & & & $<0.001$ \\
Habitat & 1 & 67.28 & 36.172 & $\mathbf{0 . 1 3 7}$ \\
Sampling site & 8 & 3.1 & 1.667 & \\
Error & 40 & 1.86 & & \\
& & & & $<0.001$ \\
Depth & 1 & 1250 & 12.184 & $<0.0001$ \\
Habitat & 8 & 628 & 6.125 & \\
Sampling site & 40 & 102.59 & & \\
Error & & & &
\end{tabular}




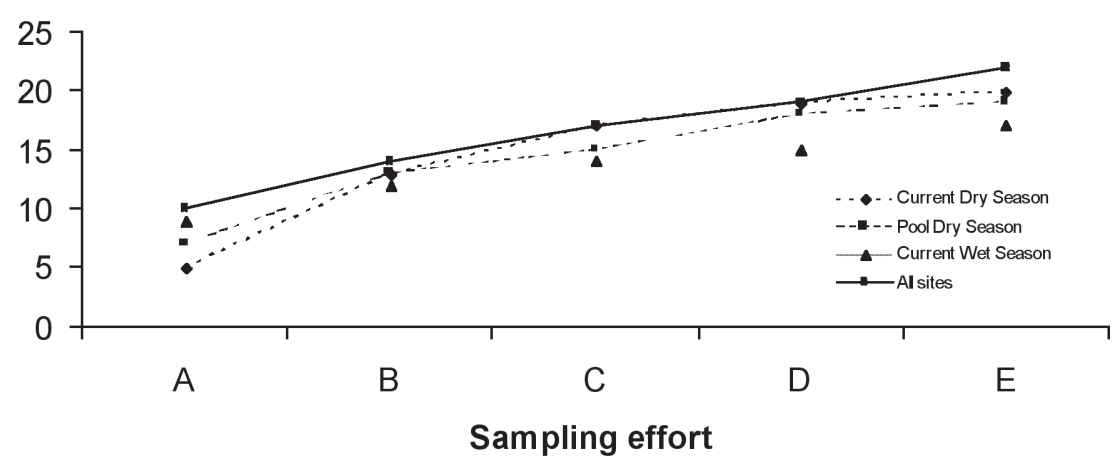

Fig. 2. Species accumulation curve for benthic insects collected at the Esparza River during 2007. The all-sites curve summarizes the total effort. The effort is measured as the sum of all samples per site at different locations.

significant variation between sampling sites, but not between habitats. The density showed variation due to the sampling site and the habitat during the dry season (Table 3 ). When the richness variability was analyzed in the temporal scale, significant differences were found between dry and wet season, and also between sampling sites nested to the temporal scale (Table 4).

\section{DISCUSSION}

The number of total specimens was lower than other studies which used different sampling tools and procedures, but similar to investigations conducted with the same procedures (Springer \& Maue, 2006). The accumulation curves show the best tendency to stabilize during the dry season (Fig. 2), which is congruent with the hypothesis of individual concentration due to the reduced water flow (Gore 1996).

Variation in spatial scale was found in both response variables (richness and abundance) (Table 4), but during the dry season there was no difference found in the (pool/current) habitats (Table 3); furthermore, no significant variation in discharge among pools and currents during the dry season was found (Table 2 ). This absence of difference in discharge

TABLE 3

Nested ANOVA for the biotic variables abundance and richness in pools and currents during the dry season at the Esparza River

\begin{tabular}{lcccc}
\multicolumn{1}{c}{ Source } & df & MS & F & p \\
Density & & & & \\
Habitat & 1 & 7638.48 & 19.528 & $<0.0001$ \\
Sampling site & 8 & 1655.1 & 4.231 & $<0.001$ \\
Error & 40 & 391.16 & & \\
& & & & \\
Richness & 1 & 6.48 & 1.409 & $\mathbf{0 . 2 4 2}$ \\
Habitat & 8 & 21.95 & 4.772 & $<0.0001$ \\
Sampling site & 40 & 4.6 & & \\
Error & & & &
\end{tabular}

$\mathrm{N}=50 . \mathrm{MS}=$ Mean squares, $\mathrm{df}=$ degrees of freedom, $\mathrm{F}=\mathrm{F}-$ test value, $\mathrm{p}=$ probability. 
TABLE 4

Nested ANOVA for the biotic variables abundance and richness in currents,

looking for differences between the dry and wet season at the Esparza River

\begin{tabular}{lcccc}
\multicolumn{1}{c}{ Source } & df & MS & F & p \\
Density & & & & $<0.0001$ \\
Season & 1 & 8791.38 & 23.648 & $<0.001$ \\
Sampling site & 8 & 1616.2 & 4.347 &
\end{tabular}

\section{Richness}

$\begin{array}{lcccc}\text { Season } & 1 & 42.32 & 13.83 & <0.001 \\ \text { Sampling site } & 8 & 18.91 & 6.18 & <0.0001 \\ \text { Error } & 40 & 3.06 & & \end{array}$

$\mathrm{N}=50 . \mathrm{MS}=$ Mean squares, $\mathrm{df}=$ degrees of freedom, $\mathrm{F}=\mathrm{F}-$ test value, $\mathrm{p}=$ Probability.

between habitats during the dry season implies that there is about the same volume of water per time unit passing through a section in the river causing the retention and accumulation of organic matter with capability enough to support similar richness values. Differences due to the sampling site could be explained by the variation along the river flow and in the configuration of the channel (Table 2), which was significantly different among habitats during the dry season, creating more accumulation of organic matter in some particular areas resulting in stochastic space variation (Vannote et al. 1980, Rosemberg \& Resh 1996).

Variation in temporal scale (wet and dry season) was also found in the response variables among sampling sites. Based on the abundance of captured specimens during the dry season (1 472 ind.) this variation in temporal scale, combined with the information presented above and the higher discharge reported during the wet season (Table 2), reinforce the idea of variation in space due to the configuration of the river.

The study zone is located in an area with evident disturbance factors like human pollution and reduction of the vegetation coverage which is likely causing alteration of non controlled variables like the amount of leaf litter available for colonization, considering that the area is surrounded by deciduous trees, and the intrinsic interaction among species or ecological groups (Fig. 1).

Community structure studies are useful in ecological integrity tools (DeShon 1995, Karr \& Chu 1999, Oberdoff et al. 2001) due to the response of the ecosystems to stress factors. Since the goal of biological evaluations is to detect and understand changes in biological systems as a result of the anthropogenic activities, it is important to determine the variation under specific circumstances; and then compare to the natural variation in pristine environments for more precise evaluations, which can provide useful information for prevention, restoration and conservation of rivers.

Up to now there have been no studies to determine the human impact on river water quality or insect community structure (in Costa Rica respectively Rio Esparza). However in the four kilometers nearest to Esparza there is evidence of solid waste and sewage flowing into the river, and deforestation of the riparian zone is another negative influence on this water body. It is also clear that, differences in the abundance and richness exists in space and time scales in this river, and data is now available using proper replication methods to 
avoid confusion among variables (Hellawel 1986, Underwood 1997). Therefore this method should be capable of providing usable data for applied ecology methodologies such as bioindication (Conesa 2000, Roldán 2003). Future studies may also incorporate multivariate techniques to evaluate higher numbers of variables which could help to determine the typology of the Costa Rican rivers.

\section{ACKNOWLEDGMENTS}

I thank Leidy Beth Otálvaro Escobar for her field and laboratory assistance and the Butterfly Conservatory for funding this project.

\section{RESUMEN}

Se estudió la estructura de la comunidad de insectos acuáticos en el río Esparza, Costa Rica, en escalas espacial y temporal. Los muestreos se realizaron durante 2007 en 5 estaciones. En mayor sequía se recolectaron cinco réplicas en cada estación en dos tipos de hábitat: corriente y pozas. En mayor precipitación se utilizó este procedimiento únicamente en la corriente. Se recolectaron los especimenes en diferentes sustratos con un cernidor y se preservaron in situ. Se analizó la variabilidad en ambas escalas con un análisis de varianza anidado cuyas variables respuesta fueron riqueza y densidad de organismos. Se efectuaron mediciones de profundidad promedio, descarga, y ancho del cauce, y se les hizo análisis de varianza. Se encontró un $51 \%$ de similaridad en riqueza entre hábitats. La riqueza analizada en la escala espacial mostró variación significativa entre sitios de muestreo pero no entre hábitats, mientras que en la escala temporal presentó diferencia entre época seca y lluviosa. La densidad mostró diferencias debido al sitio y al hábitat durante la época seca en la escala espacial, pero solo se encontró variación significativa debida al sitio de muestreo entre estaciones. Se encontró variabilidad significativa en el ancho del río en diferentes hábitats durante la época seca pero no así entre estaciones de muestreo. La profundidad mostró variación significativa entre estaciones y entre sitios de muestreo. Se discute la importancia de estudiar la estructura de la comunidad y su posible relevancia en investigación orientada a calidad de aguas.

Palabras clave: Insectos acuáticos, estructura de comunidad, integridad ecológica, río Esparza, calidad del agua, Costa Rica.

\section{REFERENCES}

Abel, P. 1989. Water pollution biology. Ellis Horwood, Chichester, England. 387 p

Bailey, R.C. 1992. Hierarchical analysis of community and habitat structure. Coenoses. 7: $127-135$.

Boyero, L. \& R.C. Bailey. 2001. Organization of macroinvertebrate communities at a hierarchy of spatial scales in a tropical stream. Hydrobiologia. 464: $219-225$.

Conesa, V. 2000. Guía Metodológica para la evaluación del Impacto ambiental. $3^{\circ}$ Ed. Ediciones Mundiprensa. Madrid. $412 \mathrm{p}$.

DeShon, J. E. 1995. Development and application of the invertebrate community index (ICI). p. 217-243. In: W.S. Davis \& T.P. Simon (eds). Biological assessment and criteria: tools for water resource planning and decision making. CRC Press, Boca Raton, FL, U.S.A.

Gore, J. 1996. Discharge measurements and streamflow analysis. p. 53 - 74. In: R. Hauer \& G. Lambert (Eds). Stream Ecology. Academic Press. California. USA.

Hellawell, J.M. 1986. Biological indicators of freshwater pollution and environmental management. Elsevier, England. 546 p.

Holdridge, R. L. 1967. Life zones ecology. San José. Costa Rica. Tropical Science Center. 216 p.

Karr, J.R. \& E.W. Chu. 1999. Restoring Life in Running Waters: Better Biological monitoring. Island Press. Washington, DC, U.S.A. 206p.

Krebs, C.J. 1999. Ecological Methodology. Segunda edición. Addison-Welsey Educational Publishers, Inc. EEUU. 620p.

Moya, N., \& T. Oberdorff. 2006. Índice multimétrico de integridad biótica para la cuenca del río Chipirri, Cochabamba-Bolivia. Rev. Bol. Ecol. 19: 01-11.

Oberdorff, T.; D. Pont; B. Hugheny \& D. Chessel. 2001. A probabilistic model characterizing riverine fish communities of French rivers: a framework for environmental assessment. Freshwater Biology 46: 399-415.

Roldán, G. R. 1996. Guía para el estudio de los Macroinvertebrados acuáticos del Departamento de Antioquia. Editorial Presencia, Bogotá. 217 p. 
Roldán, G., 2003. Bioindicación de la calidad del agua en Colombia: Propuesta para el uso del método BMWP/ Col. Colección Ciencia y Tecnología, Editorial Universidad de Antioquia, Colombia, 170 p.

Rosemberg, D. M. \& V.H. Resh. 1993. Freshwater biomonitoring and benthic macroinvertebrates. Chapman \& Hall, New York. 488 p.

Rosemberg, D. M. \& V.H. Resh. 1996. Use of aquatic insects in biomonitoring In: Aquatic Insects of North American, Ed. By R.W. Merrit \& K.W. Cummins. Third Ed. Dubuque, Iowa, Kendall / Hunt Publishing. Company. 877 p.

Springer M. \& T. Maue. 2006. Effect of methodology on the measurement of tropical aquatic macroinvertebrate taxa richness and water quality index. Rev. Biol. Trop. 54:
Stein, H., M. Springer \& B. Kohlmann. 2007. Comparision of two sampling methods for biomonitoring using aquatic macroinvertebrates in the Dos Novillos Watershed, Costa Rica. Ecological Engineering. In press.

Underwood, A. J. 1997. Experiments in Ecology: Their logical design and interpretation using analysis of variance. Cambridge University Press. Cambridge. England. 504 p.

USEPA. 1997. Volunteer Stream Monitoring: A Methods Manual. EPA 841 - B - 97 - 003. November. Office of Water 4053F. Washington DC 20460. 227 p.

Vannote, R., G. Minshall, K. Cummins, R. Sedell \& C. Cushing.1980. The river continuum concept. Canadian Journal of Fisheries and Aquatic Sciences. 37: 130-137. 
